\title{
Numeryczne modelowanie zjawiska dyspersji fizycznej - modyfikacja pełnowymiarowego symulatora złożowego
}

\begin{abstract}
W artykule przedstawiono praktyczne rozwiązanie dla modelowania zjawiska mieszania się gazów w złożu w postaci niezbędnych modyfikacji pełnowymiarowego symulatora złożowego typu black oil. Modyfikacje te objęły zagadnienia redukcji efektu dyspersji numerycznej oraz wprowadzenie numerycznego opisu zjawiska dyspersji fizycznej. Zastosowaną metodę przetestowano na trójwymiarowym modelu złoża opisującym procesy wzajemnego wypierania mieszających się gazów (zatłaczanego i rodzimego).
\end{abstract}

Słowa kluczowe: dyspersja numeryczna, dyspersja fizyczna, mieszanie się gazów, symulator złożowy.

\section{Numerical Modeling of Physical Dispersion in Porous Rock - Implementation in 3-D Reservoir Simulator}

The paper presents a practical solution of gas-mixing modelling in a reservoir by the appropriate modifications of a full-size black oil reservoir simulator. These modifications included techniques for the reduction of numerical dispersion and implementation of physical dispersion phenomena. The method was tested on a 3-D reservoir model of the deposit describing the processes of mutual displacement of miscible gases.

Key words: numerical dispersion, physical dispersion, gas mixing, reservoir simulator.

\section{Wstęp}

Dyspersja fizyczna zachodzącą podczas mieszania się gazów (rodzimego z buforowym) w podziemnych magazynach ma bardzo istotny wpływ na późniejszy przebieg ich pracy [7]. Niestety w konwencjonalnych symulatorach złożowych (np. Eclipse firmy Schlumberger lub Imex firmy CMG) zjawisko to nie znalazło odpowiedniego rozwiązania. Niniejsza praca stanowi próbę budowy w pełni wymiarowego symulatora złożowego (poprzez modyfikację ogólnodostępnego symulatora złożowego BOAST [3]) poprawnie uwzględniającego zjawisko dyspersji fizycznej. Jest ona rozszerzeniem poprzedniej pracy autorów, w której zaprezentowano rozwiązania dla jednego i dwóch wymiarów [4]. Poprawne modelowanie zjawiska mieszania się gazów wymagało zaimplementowania w symulatorze hybrydowej metody minimalizującej niepożądaną dyspersję numeryczną (mobilność z ważeniem wielopunktowym w kierunku napływu + podwójna siatka dyskretyzacji) oraz rozszerzenia standardowych równań nasyceń o dodatkowy człon dyspersji fizycznej o zadanych parametrach. W pracy użyto jednoskładnikowego przybliżenia modelu gazu wypieranego i wypierającego, opisanego w rozdziale poniżej.

\section{Ograniczenie dyspersji numerycznej}

Dyspersja numeryczna, będąca wynikiem niedokładności obliczeń symulatorów bazujących na schemacie różnic skończonych, nie może być całkowicie usunięta, gdyż jej obecność zapewnia stabilność pracy symulatora. Natomiast do poprawnego modelowania zjawiska mieszania się gazów konieczne jest ograniczenie wielkości dyspersji numerycznej 
do poziomu niezniekształcającego efektu dyspersji fizycznej. Zaproponowana $w$ ramach pracy metoda ograniczająca dyspersję jest połączeniem następujących dwóch mechanizmów:

1) mobilność efektywna - jako średnia $z$ ważeniem wielopunktowym w kierunku napływu (multipoint upstream weighting [9]),

2) podwójna siatka dyskretyzacji [1].

Pierwszy z nich został już częściowo zaimplementowany, w symulator BOAST, w postaci dwupunktowego ważenia dla obliczeń mobilności płynów (two-point upstream weighting for fluid mobility [8]). Mechanizm ten rozszerzono do wielopunktowego ważenia i stwierdzono, że zwiększanie ilości punków biorących udział w obliczaniu mobilności płynów (powyżej trzech) jest nieefektywne. Technika ta polega na sprawdzeniu kierunku przepływu dowolnego płynu (np. gazu zatłaczanego) i obliczeniu przepuszczalności względnej między blokami na podstawie przepuszczalności względnych występujących w sąsiednich blokach, np. dla przepływu pomiędzy blokiem $i$ a $i+1$ odpowiedni wzór to:

$$
k_{r, i+\frac{1}{2}}=\frac{11}{6} k_{r i}-\frac{7}{6} k_{r, i-1}+\frac{2}{6} k_{r, i-2}
$$

dla przepływów pomiędzy $i-1$ a $i$ :

$$
k_{r, i-\frac{1}{2}}=\frac{11}{6} k_{r, i-1}-\frac{7}{6} k_{r, i-2}+\frac{2}{6} k_{r, i-3}
$$

$i$ analogicznie dla przypływów w kierunkach $j$ i $k$ :

$$
\begin{aligned}
& k_{r, j+\frac{1}{2}}=\frac{11}{6} k_{r, j}-\frac{7}{6} k_{r, j-1}+\frac{2}{6} k_{r, j-2} \\
& k_{r, j-\frac{1}{2}}=\frac{11}{6} k_{r, j-1}-\frac{7}{6} k_{r, j-2}+\frac{2}{6} k_{r, y j-3} \\
& k_{r, k+\frac{1}{2}}=\frac{11}{6} k_{r, k}-\frac{7}{6} k_{r, k-1}+\frac{2}{6} k_{r, k-2} \\
& k_{r, k-\frac{1}{2}}=\frac{11}{6} k_{r, k-1}-\frac{7}{6} k_{r, k-2}+\frac{2}{6} k_{r, k-3}
\end{aligned}
$$

gdzie współczynniki stojące przy przepuszczalnościach względnych sąsiadujących bloków uzyskano poprzez rozwinięcie w szereg Taylora pochodnej cząstkowej, np. w otoczeniu punktu $x_{i}$ :

$$
\left.\frac{\partial k_{r}}{\partial x}\right|_{i} \approx \frac{k_{r, i+1 / 2}-k_{r, i-1 / 2}}{\Delta x}
$$

Powyższe wzory nie mają zastosowania w przypadkach, w których pomiędzy dwoma blokami może nastąpić przepływ tylko jednego z płynów (np. obydwa bloki nasycone są jedynie gazem rodzimym). Wówczas przepuszczalności względnej tego płynu przypisywana jest wartość 1, a przepuszczalnościom względnym „nieobecnych” płynów wartość 0 .

W celu uniknięcia niefizycznych wartości wynikających z niedokładności obliczeń przepuszczalności względnych między blokami do symulatora wprowadzono ograniczenia, które w razie wyliczenia ujemnych bądź większych od 1 przepuszczalności względnych dla danego płynu przypisują wartości 0 lub 1 - w zależności od przekroczonego limitu. Innym praktycznym ograniczeniem jest warunek, aby przepuszczalność względna między dwoma blokami nie była większa niż przepuszczalność względna w bloku, z którego następuje przepływ.

Drugim zastosowanym w pracy mechanizmem ograniczającym wielkość dyspersji numerycznej jest użycie podwójnej siatki dyskretyzacji. Ponieważ symulator złożowy BOAST wykonuje obliczenia z wykorzystaniem metody IMPES (Implicit Pressures, Explicit Saturations) [5], jest możliwe rozdzielenie tych obliczeń i wykonanie ich na różnych siatkach modelu. Podejście takie umożliwia zmniejszenie dyspersji numerycznej, nie powodując znacznego wydłużenia czasu symulacji. W metodzie tej w każdym nowym kroku czasowym symulacji nasycenia w blokach skalkulowane są na podstawie nasyceń wyliczonych w poprzednim kroku czasowym, natomiast ciśnienia w tych blokach liczone są implicite z układu równań w każdym kroku czasowym. Obliczenia nasyceń w blokach modelu są znacznie mniej skomplikowane i mniej czasochłonne niż te, które dotyczą ciśnień (dla nich używane są iteracyjne metody linearyzacji układu równań). $\mathrm{Z}$ tego powodu zastosowana $\mathrm{w}$ omawianej pracy metoda ograniczająca dyspersję numeryczną polega na wykorzystaniu do obliczeń symulacji dwóch siatek modelu: coarse grid (siatka niezagęszczona) do obliczeń ciśnień oraz fine grid (siatka zagęszczona) do obliczeń nasyceń.

W celu wykorzystania ciśnień uzyskanych na niezagęszczonej siatce modelu do obliczeń nasyceń zastosowano procedurę interpolacyjną przypisującą wyinterpolowane wartości ciśnień blokom zagęszczonej siatki. Zastosowana dla trzech wymiarów procedura interpolacji opiera się na wielomianach Lagrange'a i przyjmuje postać wielomianu trzeciego stopnia dla każdej z trzech współrzędnych $x, y, z$ :

$$
\begin{gathered}
P(x, y, z)=\sum_{i=-2,-1,1,2} \sum_{j=-2,-1,1,2} \sum_{k=-2,-1,1,2} P\left(x_{i}, y_{j}, z_{k}\right) \\
\prod_{\substack{l \neq i \\
l=-2,-1,1,2}}\left(\frac{x-x_{l}}{x_{i}-x_{l}}\right) \prod_{\substack{m \neq j \\
m=-2,-1,1,2}}\left(\frac{y-y_{m}}{y_{j}-y_{m}}\right) \prod_{\substack{n \neq k \\
n=-2,-1,1,2}}\left(\frac{z-z_{n}}{z_{k}-z_{n}}\right)
\end{gathered}
$$

gdzie: $x_{\mathrm{i}}, x_{l}, y_{j}, y_{m}, z_{k}, z_{n}$ są współrzędnymi węzłów siatki niezagęszczonej w sąsiedztwie obliczanego punktu $x, y, z$, 
których wzajemne położenie przedstawiono poniżej (dla przypadku 2 współrzędnych).

Tak opisaną interpolację wykorzystano do określenia ciśnień wewnątrz modelowanego obszaru, a w przypadkach bloków skrajnych zastosowano wartości zapewniające zerowy gradient, prostopadle do brzegu modelu. Wyniki nasyceń oraz innych wielkości będących ich funkcjami przypisywano właściwym blokom siatki niezagęszczonej poprzez średnie ważone objętością bloków lub ich powierzchnią boczną.

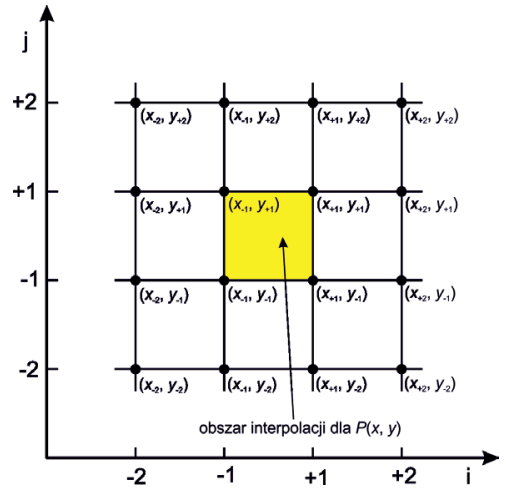

Rys. 1. Sposób interpolacji ciśnień przy podwójnej siatce dyskretyzacji

\section{Mieszanie się gazów (dyspersja fizyczna)}

Występująca w strukturach węglowodorowych dyspersja fizyczna [2] jest to proces rozmycia profilu stężenia płynu, wywołany niejednorodnością pola prędkości konwekcyjnej, powstałą na skutek złożonego przepływu przez ośrodek porowaty. Analogiczny efekt jest również skutkiem występowania dyfuzji molekularnej wynikającej z gradientu koncentracji. Uwzględnienie tych zjawisk w symulatorze złożowym wymagało wprowadzenia do równań nasyceń dodatkowego członu opisującego te zjawiska.

W prezentowanym podejściu użyto uproszczenia w postaci „modelu jednoskładnikowego”, tzn. nie uwzględniono szczegółowego składu gazu wypierającego i wypieranego, ale potraktowano je jako gazy o pojedynczych składnikach, co upraszcza opis dyspersji/dyfuzji, a nie zmienia podstawowych cech zjawiska mieszania. Dodatkowo na prezentowanym etapie zaniedbano różnice we właściwościach gazów: gęstości $\left(\rho_{1}=\rho_{2}=\rho\right)$, współczynnikach objętościowych $\left(B_{1}=B_{2}=B\right)$ i innych. Przy takich założeniach ułamki molowe $\left(x_{1}, x_{2}\right)$ rozpatrywanych gazów są identyczne $\mathrm{z}$ ich nasyceniami $\left(S_{1}, S_{2}\right)$ - Dodatek.

Standardowo stosowane w symulatorach równanie dla nasycenia jest konwekcyjne i nie uwzględnia zjawiska dyspersji/dyfuzji. W procesie dyskretyzacji tego równania powstaje błąd, będący tzw. dyspersją numeryczną (minimalizowaną w ramach pracy), zmieniający jego postać do równania konwekcji-dyfuzji. Rozszerzając to równanie o dyspersję fizyczną, otrzymamy w przybliżeniu (przy założeniu stacjonarnych ciśnień w modelu) postać:

$$
\left(D_{\text {phys }}+D_{\text {num }}\right) \overrightarrow{\nabla^{2}} S-\overrightarrow{v_{t}} \vec{\nabla} S=\phi_{\text {eff }} \frac{\partial S}{\partial t}
$$

gdzie: $S$ - to nasycenie gazem wypierającym, a $\overrightarrow{v_{t}}$ - to prędkość całkowita, $\overrightarrow{v_{t}}=\overrightarrow{v_{1}}+\overrightarrow{v_{2}}$ - będąca sumą prędkości dwóch mieszających się składników.
Tak jak w przypadku jednego czy dwóch wymiarów, techniczne uwzględnienie dyspersji fizycznej polegało na dodaniu do symulatora jawnego członu dyspersji o zadanych parametrach. We wszystkich kierunkach założono liniową zależność dyspersji od prędkości przepływu:

$$
\begin{aligned}
& D_{\text {phys }, x}=D_{x}+\alpha \vec{v}_{x} \\
& D_{\text {phys }, y}=D_{y}+\alpha \vec{v}_{y} \\
& D_{\text {phys }, z}=D_{z}+\alpha \vec{v}_{z}
\end{aligned}
$$

Tak określone parametry dyspersji fizycznej uwzględniono w równaniu na przepływy gazu z/do bloków sąsiednich do/z bloku o współrzędnych $i, j, k$ :

$$
\begin{aligned}
\bar{Q}_{g}= & \overline{K A_{c l}} \frac{k_{r g, x}}{\mu_{g} B_{g}} \frac{p_{i-1}-p_{i}}{\frac{\Delta x_{i-1}+\Delta x_{i}}{2}}+\overline{D_{p h y s, x} A_{c l}} \frac{S_{i-1}-S_{i}}{B_{g} \frac{\Delta x_{i-1}+\Delta x_{i}}{2}} \\
& +\overline{K A_{c l}} \frac{k_{r g, y}}{\mu_{g} B_{g}} \frac{p_{j-1}-p_{j}}{\frac{\Delta y_{j-1}+\Delta y_{j}}{2}}+\overline{D_{p h y s, y} A_{c l}} \frac{S_{j-1}-S_{j}}{B_{g} \frac{\Delta y_{j-1}+\Delta y_{j}}{2}} \\
& +\overline{K A_{c z}} \frac{k_{r g, z}}{\mu_{g} B_{g}} \frac{p_{k-1}-p_{k}}{\frac{\Delta z_{k-1}+\Delta z_{k}}{2}}+\overline{D_{p h y s, z} A_{c z}} \frac{S_{k-1}-S_{k}}{B_{g} \frac{\Delta z_{k-1}+\Delta z_{k}}{2}}(9)
\end{aligned}
$$

gdzie:

$\bar{K}$ - przepuszczalność absolutna,

$\overline{A_{c l}}, \overline{A_{c l}}, \overline{A_{c z}}$ - pola przekrojów poprzecznych pomiędzy blokami (pomiędzy $x_{i-1}$ i $x_{i}, y_{j-1}$ i $y_{j}, z_{k-1} \mathrm{i} z_{k}$ ),

$k_{r, g, x}, k_{r, g, z}$ - przepuszczalności względne gazu wypierającego w różnych kierunkach,

$\mu$ - lepkość objętościowa gazu wypierającego,

$B_{g}$ - współczynnik objętościowy gazu wypierającego,

$\Delta x_{i}, \Delta y_{j}, \Delta z_{k}$ - rozmiary bloków w różnych kierunkach,

$p_{i, j, k}$ - ciśnienia w blokach,

$S_{i, j, k}-$ nasycenia gazem wypierającym. 


\section{Pełnowymiarowy model PMG}

Wszystkie zmiany wprowadzone do symulatora testowano na uproszczonym trójwymiarowym modelu PMG scharakteryzowanym przez: rozmiar $10 \times 10 \times 5$ o wymiarach około $20 \times 20 \times 20 \mathrm{ft}$, stałą porowatość $\phi=0,15$ i stałą przepuszczalność bezwzględną $K=50 \mathrm{mD}$, przy braku wody złożowej. Modelowanie z pełnym uwzględnieniem zróżnicowanych właściwości gazów zatłaczanego i rodzimego będzie tematem publikacji dotyczącej rzeczywistych obiektów.

W modelu założono pracę dwóch odwiertów zlokalizowanych na przeciwległych krańcach, z czego pierwszy - zatłaczający, WI, udostępniono w pierwszej warstwie, natomiast drugi - produkcyjny, WP, w ostatniej warstwie (rysunek 1). W przypadku odwiertów tych założono identyczne wydajności zatłaczania/odbioru na poziomie 164.1684 tys. $\mathrm{ft}^{3} /$ day, w wyniku czego w trakcie symulacji (po wyrównaniu ciśnień) uzyskano stacjonarny przepływ gazów.

Wyniki zastosowania proponowanej procedury ograniczającej dyspersję numeryczną przedstawiono na rysunkach 4 i 5. Natomiast rysunek 3, dla porównania, przedstawia wynik symulacji bez stosowania tej procedury. Za najlepszy wynik ograniczenia dyspersji numerycznej, w przypadku tego modelu, uznano zastosowanie trzypunktowego ważenia dla obliczeń mobilności płynów wraz z dziewięciokrotnym zagęszczeniem siatki dla obliczeń nasyceń (rozmycie frontu mieszania się gazów ograniczono z kilkudziesięciu do kilku ft). Dalsze zagęszczanie siatki przynosi pożądany efekt w postaci mniejszej dyspersji numerycznej, lecz z każdym kolejnym zagęszczaniem efekt ten jest coraz mniejszy, a wzrastająca ilość bloków, dla których liczone są nasycenia, znacznie wydłuża czas obliczeń.

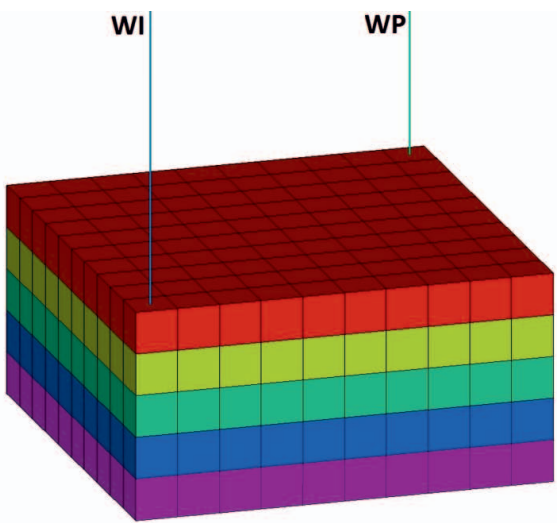

Rys. 2. Trójwymiarowy widok modelu PMG. Rozmieszczenie odwiertów biorących udział w symulacjach
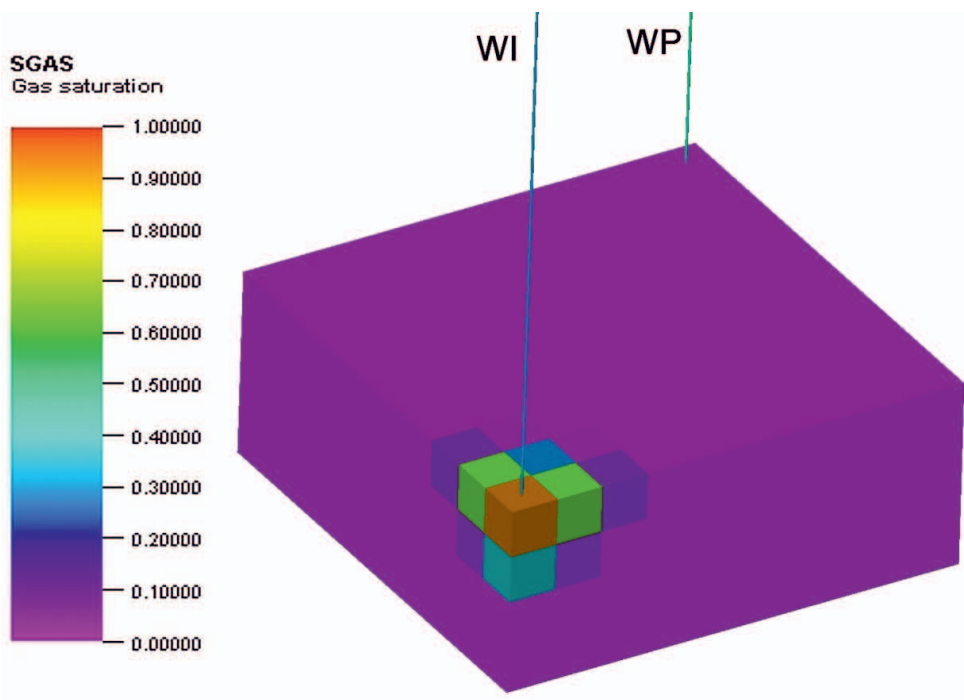

Rys. 3. Trójwymiarowy widok modelu PMG. Nasycenie gazem zatłaczanym. Wynik symulacji bez ograniczenia dyspersji numerycznej $(t=10 \mathrm{~d})$
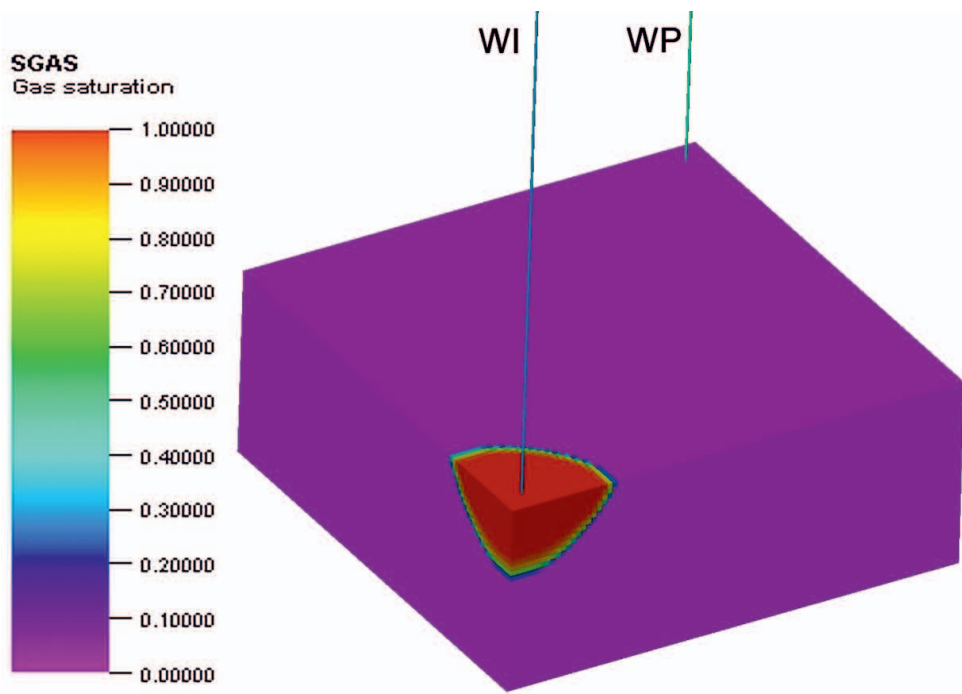

Rys. 4. Trójwymiarowy widok modelu PMG. Nasycenie gazem zatłaczanym. Wynik symulacji z ograniczeniem dyspersji numerycznej $(t=10 \mathrm{~d})$ 


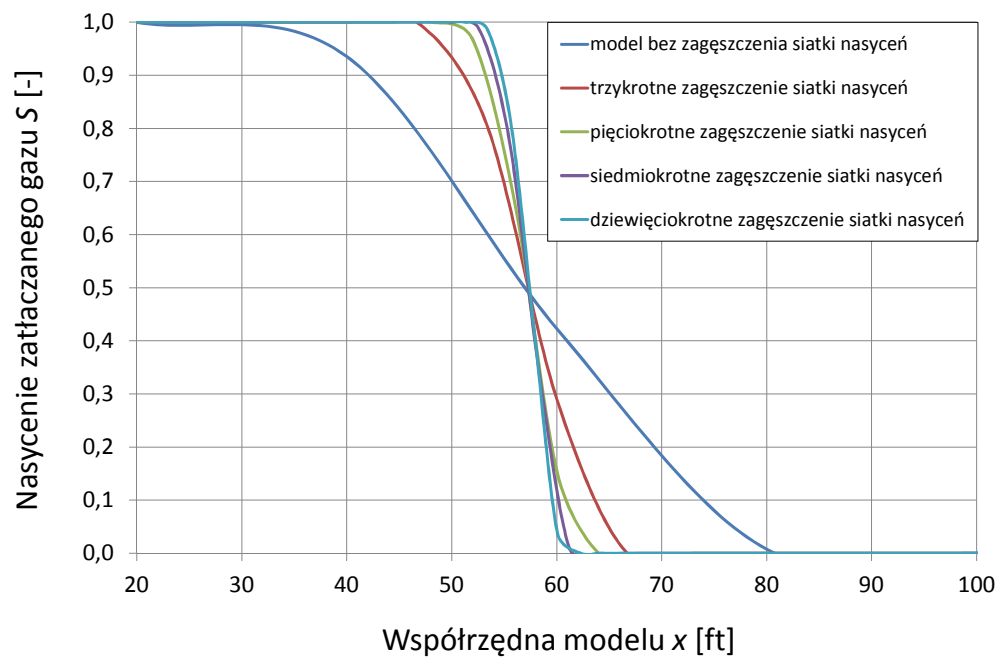

Rys. 5. Nasycenie gazu zatłaczanego w funkcji współrzędnej modelu w kierunkach $X, Y, Z$ dla wybranego zestawu bloków $(t=10 \mathrm{~d})$

\section{Sterowanie zjawiskiem mieszania się gazów}

Przy użyciu zmodyfikowanego symulatora złożowego, po optymalnym zminimalizowaniu dyspersji numerycznej, wykonano symulacje $\mathrm{z}$ kontrolowanym rozmyciem frontu mieszania się gazów, poprzez zadanie czterech parametrów dyspersji fizycznej, a mianowicie: $D_{x}, D_{y}, D_{z}$ oraz $\alpha$, które określają liniowe zależności dyspersji od prędkości przepływu w danym kierunku.

Rysunek 6 przedstawia wynik zastosowania takich samych parametrów dyspersji fizycznej we wszystkich kierunkach, w efekcie czego uzyskano symetryczne rozmycie frontu mieszania się gazów większe od rozmycia otrzymanego po zminimalizowaniu dyspersji numerycznej (rysunek 4). Natomiast rysunek 7 przedstawia wyniki zastosowania różnych wielkości dyspersji fizycznej, w zależności od kierunku przepływu gazu. Rozmycie frontu mieszania się gazów w tym przypadku nie jest symetryczne i zależy od wielkości zadanego parametru $D$ dla wybranego kierunku.

Umożliwione w zmodyfikowanym symulatorze zadawanie różnych parametrów dyspersji, w zależności od kierunku przepływu gazów, w znacznym stopniu ułatwi kalibrację modelu PMG, ponieważ zjawisko dyspersji zachodzące w rzeczywistości zależy od parametrów złożowych, a ich wartości nie rozkładają się symetrycznie we wszystkich kierunkach.
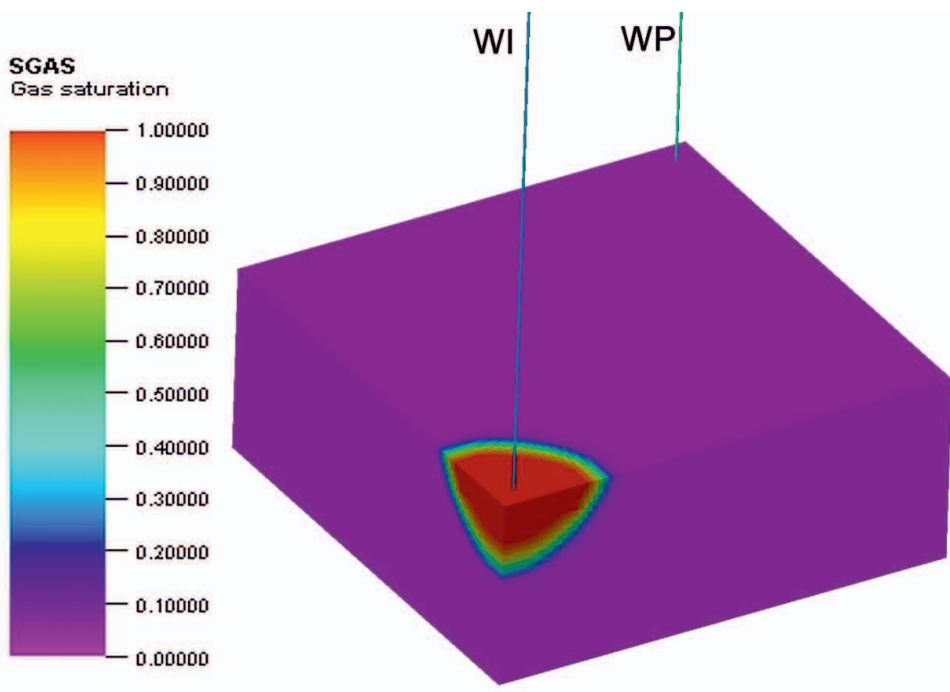

Rys. 6. Trójwymiarowy widok modelu PMG. Nasycenie gazem zatłaczanym. Parametry dyspersji fizycznej: $D x, D y, D z=10 \mathrm{ft}^{2} / \mathrm{d}, \alpha=0,5 \mathrm{ft}(t=10 \mathrm{~d})$

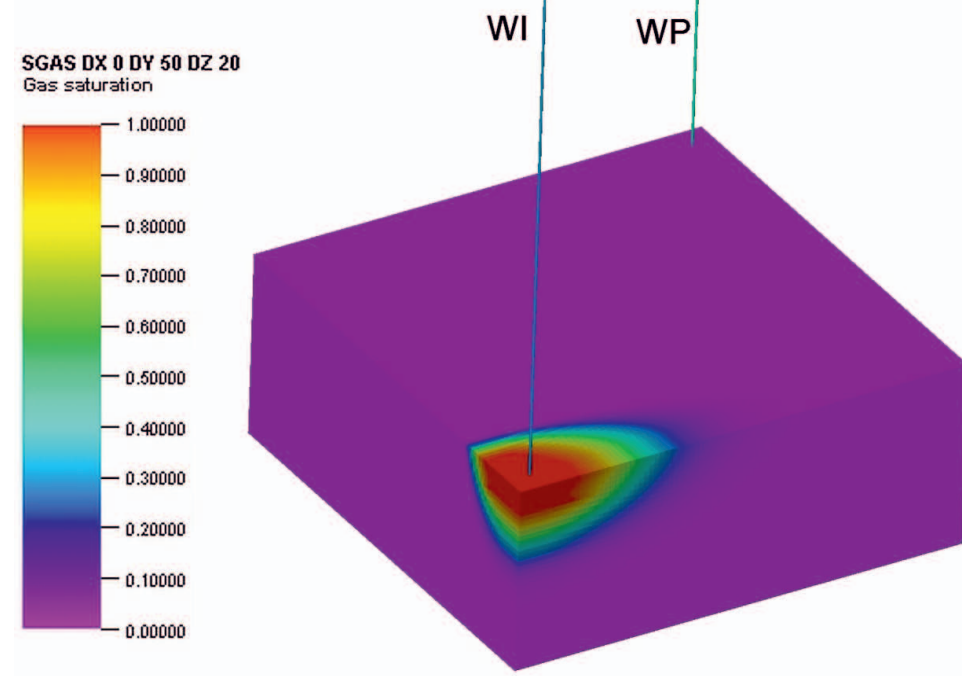

Rys. 7. Trójwymiarowy widok modelu PMG. Nasycenie gazem zatłaczanym. Parametry dyspersji fizycznej: $D x=0, D y=50, D z=20 \mathrm{ft}^{2} / \mathrm{d}$, $\alpha=0,5 \mathrm{ft}(t=10 \mathrm{~d})$ 


\section{Podsumowanie}

W pracy przedstawiono zagadnienie dotyczące numerycznego modelowania zjawiska mieszania się gazów występującego podczas wytwarzania buforu oraz regularnej pracy PMG. Ponieważ standardowe symulatory złożowe (typu Eclipse czy CMG) nie posiadają opcji pozwalających na poprawne modelowanie zjawiska dyspersji fizycznej, w ramach niniejszej pracy zbudowano narzędzie (zmodyfikowano symulator złożowy BOAST) umożliwiające symulowanie tego zjawiska. W tym celu w symulatorze:
- zaimplementowano hybrydową metodę ograniczającą dyspersję numeryczną, łączącą zastosowanie obliczeń mobilności z ważeniem trzypunktowym w kierunku napływu z podwójną siatką dyskretyzacji (niezagęszczona siatka do obliczeń ciśnień i zagęszczona do obliczeń nasyceń), - rozszerzono o człon dyspersyjny równania przepływu płynów między blokami.

Zaproponowaną w pracy metodę przetestowano na uproszczonym trójwymiarowym modelu symulacyjnym PMG.

\section{Dodatek}

Koncentracje molowe gazu wypierającego, $c_{1}$, i wypieranego, $c_{2}$, są zależne od ich nasyceń $\left(S_{1}, S_{2}\right)$, gęstości $\left(\rho_{1}, \rho_{2}\right)$, współczynników objętościowych $\left(B_{1}, B_{2}\right)$ i ciężarów molowych $\left(M W_{1}, M W_{2}\right)$, zgodnie ze wzorem:

$$
c_{i}=\frac{S_{i} \rho_{i}}{B_{i} M W_{i}} \quad i=1,2
$$

natomiast ich ułamki molowe to: $x_{i}=\frac{c_{i}}{c}$, gdzie $c=c_{1}+c_{2}$.

Strumień gazu $\vec{J}_{i}$ na skutek efektu dyspersji/dyfuzji wyraża się wzorem [9]:

$$
\vec{J}_{i}=-c D_{i} \vec{\nabla} x_{i}
$$

gdzie: $D_{i}$ to stałe dyfuzji/dyspersji $i$-tego gazu.
Z założenia identycznych własności obu gazów $\left(\rho_{1}=\rho_{2}=\rho, B_{1}=B_{2}=B, M W_{1}=M_{2}=M W\right)$ wynika:

$$
c=\frac{\rho}{B M W}, \quad x_{i}=S_{i}
$$

Z warunku ciągłości otrzymujemy:

$$
\vec{\jmath}_{1}=-\vec{\jmath}_{2}, \quad \vec{\nabla} S_{1}=-\vec{\nabla} S_{2}
$$

czyli $\vec{\jmath}_{1}=-c D_{1} \vec{\nabla} S_{1}=-\vec{\jmath}_{2}=c D_{2} \vec{\nabla} S_{2}=-c D_{2} \vec{\nabla} S_{1}$ tzn. $c D_{1}=c D_{2}=c D_{\text {eff }}$

Wynika stąd, że w zastosowanym przybliżeniu ułamek molowy można utożsamić z nasyceniem gazem $x_{i}=S_{i}$, a proces dyspersji/dyfuzji opisać efektywną stałą $D_{p h y s}=D_{\text {eff: }}$ Odpowiedni człon w równaniach różnic skończonych przyjmuje wówczas postać wcześniej podanej zależności (9).

Prosimy cytować jako: Nafta-Gaz 2016, nr 7, s. 528-533, DOI: 10.18668/NG.2016.07.05

Artykuł nadesłano do Redakcji 10.11.2015 r. Zatwierdzono do druku 6.04.2016 r.

Artykuł powstał na podstawie pracy statutowej pt. Trójwymiarowy symulator złożowy umożliwiajacy modelowanie mieszania się gazów - praca INiG - PIB na zlecenie MNiSW; nr zlecenia: 40/KZ/15, nr archiwalny: DK-4100-40/15.

\section{Literatura}

[1] Audigane P., Blunt M. J.: Dual mesh method in upscaling. SPE 79681, 2003.

[2] Bijeljic B., Blunt M. J.: A Physically-Based Description of Dispersion in Porous Media. SPE-102869-MS, 2006.

[3] Fanchi J. R., Harpole K. J., Bujnowski S. W.: BOAST: A three-dimensional, three-phase black oil applied simulation tool (Version 1.1) Volume 1: Technical Description and FORTRAN Code. Bartlesville Energy Technology Center, 1982.

[4] Gołąbek A., Szott W.: Modyfikacje symulatora złożowego dla potrzeb modelowania zjawisk mieszania się gazów. Nafta-Gaz 2015, nr 3, s. 177-184.

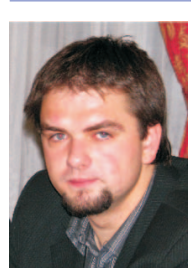

Mgr inż. Andrzej GOŁĄBEK

Asystent w Zakładzie Symulacji Złóż Węglowodorów i Podziemnych Magazynów Gazu.

Instytut Nafty i Gazu - Państwowy Instytut Badawczy

ul. Lubicz $25 \mathrm{~A}$

31-503 Kraków

E-mail: andrzej.golabek@inig.pl
[5] Peaceman D. W.: Fundamentals of numerical reservoir simulation. Elsevier Scientific Publishing Company, 1977.

[6] Reid R. C., Prausnitz J. M., Polling B. E.: The Properties of Gases and Liquids. McGraw-Hill, New York 1987.

[7] Szott W.: Zastosowanie symulacji komputerowych do modelowania pracy podziemnych magazynów gazu w Polsce. Nafta-Gaz 2010, nr 5, s. 339-344.

[8] Szott W., Gołąbek A.: Symulacyjne modelowanie procesów mieszania się gazów w warunkach złożowych. Nafta-Gaz 2014, nr 3, s. 151-161.

[9] Tood M. R., O'Dell P. M., Hirsaki G. J.: Methods for Increased Accuracy in Numerical Reservoir Simulators. SPE 3516, 1972.

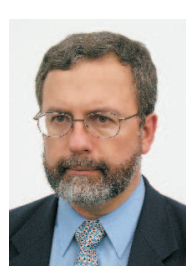

Dr Wiesław Szott

Adiunkt; kierownik Zakładu Symulacji Złóż

Węglowodorów i Podziemnych Magazynów Gazu. Instytut Nafty i Gazu - Państwowy Instytut Badawczy ul. Lubicz 25 A

31-503 Kraków

E-mail: wieslaw.szott@inig.pl 